\title{
PEMIKIRAN ANNEMARIE SCHIMMEL TENTANG SIFAT FEMININ DALAM TASAWUF
}

\author{
Ahmad Purwanto \\ Kantor Urusan Agama (KUA) Kementerian Agama Kec. Kalikajar \\ Wonosobo-Jawa Tengah \\ e-mail:aby1504@gmail.com
}

Abstract: The article explores the ideas of Annemarie Schimmel relating to aspects of feminism in Sufism. According to Schimmel, that Sufism, or mystical Islam is the awareness of a single reality and love of the Absolute, because the forces that separate the true mystic by asceticism is love. Even true love can make enjoyment of all that painful. Mystical considered a mysterious thing that can not be achieved by ordinary means or by intellectual effort. While the literature and difficult spiritual life depicted as blind men touching an elephant, in pengambaraannya will say according to the elephant body parts are touched. While the nature of feminine in Sufism has been revealed as to uncover the elements of womanhood is in Sufism itself, like having love, affection, obedient, patient, prejudiced either (husnu zan), and willing to sacrifice. From here it turns keperempuan nature not only possessed by women alone, but is owned by the Sufis men.

Abstrak: Artikel ini akan mengeksplorasi pemikiran Annemarie Schimmel yang berkaitan dengan aspek feminisme (keperempuan) dalam tasawuf. Dalam pandangan Schimmel, bahwa tasawuf atau mistik Islam merupakan kesadaran terhadap kenyataan tunggal dan cinta Yang Mutlak, sebab kekuatan yang memisahkan antara mistik sejati dengan hanya sekedar tapa brata (asceticism) adalah cinta. Bahkan cinta sejati dapat menjadikan kenikmatan terhadap segala yang menyakitkan. Mistik dianggap sebagai hal yang misterius yang tidak dapat dicapai dengan cara-cara biasa atau dengan usaha intelektual. Sedangkan literature dan kehidupan rohaninya sulit digambarkan sebagaimana orang buta yang menyentuh gajah, dalam pengambaraannya akan mengatakan sesuai dengan bagian tubuh gajah yang disentuhnya. Sedangkan sifat keperempuan (feminin) dalam tasawuf telah terungkap sebagaimana mengungkap unsur-unsur kewanitaan yang ada dalam tasawuf itu sendiri, seperti memiliki cinta, kasih sayang, taat, sabar, berprasangka baik (husnu zan), dan rela berkorban. Dari sini ternyata sifat keperempuan tidak hanya dimiliki oleh perempuan saja, tetapi dimiliki oleh para sufi laki-laki.

Keywords: feminism, tasawuf, asketicisme, Jalāl, dan Jamāl. 


\section{A. Pendahuluan}

Dalam sejarah Islam, kaum perempuan selalu menjadi wacana menarik bagi setiap sisi kehidupan. Permasalahan yang dihadapi sangatlah kompleks. Mulai dari adanya perluasan koloni laki-laki, sampai pada penjelmaan perempuan yang menjadi eksploitasi bisnis maupun seks. Demikian juga dalam masalah teks-teks ajaran agama, kata 'perempuan' sering ditafsirkan dalam perspektif maskulin (laki-laki). ${ }^{1}$ Walaupun dalam kenyataannya, argu-mentasi tersebut secara kontekstual telah menyalahi kodrat kemanusiaan. Karena banyak sifat keperempuan (feminine) yang tidak tersingkap dan terungkap dalam wacana keislaman, terutama dalam tasawuf.

Menurut Said Aqil Siroj, unsurunsur feminin atau maskulin dalam wacana tasawuf bukanlah kendala yang berarti, baik laki-laki maupun perempuan memiliki peluang yang sama dalam memperoleh maqāmāt dan aḥwāl guna meniti jalan sebagai sufi sejati. Seorang yang menjadi sufi atau waliyullah tidak dipersyaratkan harus laki-laki. Persyaratan yang paling pokok adalah bagaimana kondisi kalbu manusia yang menjadi sentral kehidupan mereka, baik jasmani maupun rohani. Kekeruhan hati manusia menyebabkan gelapnya hubungan mereka kepada Tuhan sehingga obsesinya hanya tertambat pada realitas yang instan. Hati yang bersifat immateri esensinya hanya akan menyatu dengan Zat yang immateri pula, yaitu Tuhan. Sementara Tuhan merupakan Zat yang

${ }^{1}$ Dadang S. Anshori, Membincangkan $\mathrm{Fe}$ minisme: Refleksi Muslimah atas Peran Sosial Kaum Wanita, Bandung: Pustaka Hidayah, 1997, h. 3.
Quddūs (Mahasuci) tidak mungkin menyatu dengan sesuatu yang kotor. Oleh karena itu, tasawuf mengajarkan adanya proses penyucian dan pember-sihan hati (takhalli). ${ }^{2}$

Pada dasarnya, sering dijumpai bahwa sikap tasawuf terhadap wanita adalah senantiasa mendua, bahkan tasawuf lebih bersifat terbuka terhadap perkembangan kegiatan wanita dibandingkan dengan cabang-cabang kegiatan Islam lain. ${ }^{3}$ Hal ini dapat ditunjukkan dengan adanya simpati Rasulullah saw terhadap wanita; perkawinan beliau yang berkali-kali, bahkan pemujaan kepada Fatimah oleh kalangan Syi'ah. Di sisi lain, telah ditemukan adanya beberapa kisah sufi dalam al-Quran yang dapat dijadikan sebagai contoh adanya peran wanita dalam kehidupan beragama, seperi kisah istri Potiphar (Zulaikha) yang terbuai cintanya kepada Yusuf.

Di kalangan sarjana Barat seperti Annemarie Schimmel adalah yang banyak mengkaji tentang peran wanita dalam tasawuf ini. Artikel ini akan mengkaji lebih mendalam lagi pandangan Schimmel tersebut.

\section{B. Sekilas Annemarie Schimmel}

Annemarie Schimmel dilahirkan pada 7 April 1922 di Erfurt, sebuah kota kecil di Jerman bagian tengah. Sebuah kota yang memiliki sejumlah Katedral Gothik dan merupakan pusat holtikultura. Jika berkuda atau naik kereta, Erfurt dapat ditempuh hanya beberapa

2Said Aqil Siroj, Tasawuf sebagai Kritik Sosial: Mengedepankan Islam sebagai Inspirasi, Bukan Aspirasi, Bandung: Mizan, 2005, h. 254.

3Margaret Smith, Rabi'ah: Pergulatan Spiritual Perempuan, terj. Dra. Jamilah Baraja, Surabaya: Risalah Gusti, 2001, h. 157-158. 
jam dari Weimar dan Jena sebagai pusat literature Jerman klasik, karena jaraknya dekat. ${ }^{4}$

Pada 26 Januari $2003^{5}$, Annemarie Schimmel meninggal dengan meninggalkan karya-karya yang berharga tentang Islam, termasuk tasawuf. ${ }^{6}$ Sejak berusia lima belas tahun, Schimmel belajar bahasa Arab di bawah bimbingan Dr. Hens Ellenberg. Sang guru ini tidak hanya mengajarkan bahasa Arab tetapi juga sejarah dan kebudayaan Islam. Salah satu buku yang diperkenalkan sang guru adalah The Life and Teaching of Muhammad: The Spirit of Islam karya Sayed Ali dan Muhammad in Lehre vad Gloube Seiner Gemeinde karya Tor Andrae.

Ketertarikan Schimmel terhadap Islam dimulai sejak mengajar Sejarah Agama-agama di Islamic Faculty of Divinty di Ankara, Turki (1950). Tampaknya ia menyadari bahwa tasawuf merupakan salah satu inti dari Islam. Tasawuf, menurutnya, adalah aspek batin dari agama yang dibawa Nabi Muhammad saw. Sedangkan aspek lahir, yang biasanya disebut syari'ah berisi hukum-hukum keagamaan formal mengenai perintah dan larangan. Hal itulah yang selalu disampaikannya dalam setiap perkuliahannya. Dalam suatu perkuliahan, ia menjelaskan tentang kategori yang dibuat oleh Rudolf Otto tentang Mysterium Tremendum dan Mysterium Fascian-Numen yang meng-

4Lihat: Annemarie Schimmel, Jiwaku adalah Wanita: Aspek Feminin dalam Spiritual-itas Islam, terj. Eva Y. Nukman, Bandung: Mizan, 1998, h. 13.

5 https://en.wikipedia.org/

${ }^{6}$ Sachiko Murata, The Tao of Islam: Kitab Rujukan tentang Relasi Gender Dalam Kosmologi dan Teologi Islam, terj. Rahmani Astuti dan M.S. Nasrullah, Bandung: Mizan, 1999, h. 4. ungkapkan dirinya sendiri di bawah aspek keagungan yang menakjubkan dan Keindahan Yang Memikat, Allah swt, yaitu adanya konsep Maha Agung, Maha Kuasa (Jalāl) dan Maha Indah, Maha Baik, Maha Belas Kasih (Jamāll. ${ }^{7}$

Sebagai peneliti dan Islamolog ulung, secara memukau Schimmel mampu menunjukkan sikap "keber-islaman" bahkan jauh melampaui kaum Muslim sendiri. Kenyataan ini dapat dilihat melalui komitmen dan empatinya yang mendalam terhadap Islam. Karyakaryanya yang berkaitan dengan Islam sebagai berikut:

1) As Through a Veil: Mystical Poetry in Islam (New York: Columbia Univer-sity Press, 1982).

2) And Muhammad Is His Messenger: The Veneration of the Prophet in Islamic Piety (Chapel Hill: University of North Carolina Press, 1985).

3) Nightingales under the Snow: Poems (London and New York: Khaniqahi Nimatullahi Publications, 1994).

4) Anvari's Divan: A Pocket Book for Akbar (New York: Metropolitan Museum of Art, 1994).

5) A Dance of Sparks: Imagery of Fire in Ghalib's Poetry (New Delhi: Ghalib Academy, 1979).

6) A Two-Colored Brocade: The Imagery of Persian Poetry (Chapel Hill: University of North Carolina Press, 1992).

7) Deciphering the Signs of God: A Phenomenological Approach to Islam. The 1991-1992 Gifford Lectures (Albany: State University of New York Press, 1994).

${ }^{7}$ Annemarie Schimmel, Deciphering the Signs of God: A Phenomenological Approach to Islam, New York: State University of New York Press, 1994, h. X. 
8) Gabriel's Wing: Study into the Religious Ideas of Sir Muhammad Iqbal (Karachi: Iqbal Academy, 1989).

9) Mystical Dimensions of Islam (Chapel Hill: University of North Carolina Press, 1975).

10) Introducción al Sufismo (Barcelona: Editorial Kairós, 2007).

11) I Am Wind, You Are Fire: The Life and Work of Rumi (Boston: Shambhala Publications, 1997). Diterbitkan kembali dengan judul Rumi's World: The Life and Works of the Great Sufi Poet (Boston: Shambhala Publica-tions, 2001).

12) Im Reich der Grossmoguls: Geschichte, Kunst, Kultur. Munich: Verlag C.H. Beck, 2000. English translation: The Empire of the Great Mughals: History, Art, and Culture (London: Reaktion Books, 2004).

13) Look! This Is Love (Boston: Shambhala Centaur Editions, 1996).

14) The Triumphal Sun: A Study of the Works of Jalaloddinn Rumi (London: East-West Publications, 1980).

15) Islamic Literatures of India (Wiesbaden: Otto Harrassowitz Verlag, 1973).

16) Mohammad Iqbal, Poet and Philosopher: A Collection of Translations, Essays, and Other Articles (Karachi: Pakistan-German Forum, 1960).

17) Classical Urdu Literature: From the Beginning to Iqbal. A History of Indian Literature, v. 8. Wiesbaden: Otto Harrassowitz Verlag, 1975.

18) Islam: An Introduction (Albany: State University of New York Press, 1992).

19) We Believe in One God: The Experience of God in Christianity and Islam, edited by Annemarie Schimmel and Abdoldjavad
Falaturi; translated by Gerald Blaczszak and Annemarie Schimmel. London: Burns \& Oates, 1979.

20) Islamic Calligraphy. Evanston, Ill.: Adler's Foreign Books, 1970.

21) Calligraphy and Islamic Culture. New York University Press, 1990.

22) Islamic Names: An Introduction (Edinburgh University Press, 1990).

23) Meine Seele ist eine Frau (Munich: Kosel Verlag, 1995). Versi bahasa Inggris: My Soul Is a Woman: The Feminine in Islam (New York and London: Continuum, 1997).

24) Pain and Grace: A Study of Two Mystical Writers of EighteenthCentury Muslim India. Leiden: Brill, 1976.

25) The Mystery of Numbers (New York: Oxford University Press, 1993).

26) Islam and the Wonders of Creation: The Animal Kingdom. London: Al-Furqan, Islamic Heritage Foundation 2003.

27) Introduction to Cats of Cairo: Egypt's Enduring Legacy, with photographs by Lorraine Chittock. New York: Abbeville Press, 1995. Reissued as Cairo Cats: Egypt's Enduring Legacy (American University in Cairo Press, 2005).

\section{Pemikiran Schimmel tentang Aspek Feminin dalam Tasawuf}

Kata feminism berasal dari bahasa latin femina, yang berarti memiliki sifat keperempuanan. Feminism adalah halhal yang berkenaan dengan wanita. Pada dasarnya feminim berbeda dengan kewanitaan (feminity), karena feminism lebih cenderung pada sifat kewanitaan atau keperempuannya, sedangkan feminity adalah sifat dari feminism. Berbeda 
pula dengan feminist, yaitu berusaha mengajak untuk memberikan hak-hak secara berlebihan kepada perempuan. ${ }^{8}$

Menurut Schimmel perempuan merupakan ungkapan rahasia dari Allah SWT. Karena kreatif Tuhan terungkap paling jelas pada perempuan, bukan boleh dikatakan bahwa se-benarnya "wanita tidak diciptakan oleh sang pencipta". 9 Sedangkan dalam kesusastraan Parsi, perenungan Ilahi dalam bentuk perempuan dengan dilambangkan melalui kisah Layla dan Majnun. Begitu juga dengan kisah klasik mengenai peran perempuan dalam teori cinta mistik oleh Syekh San'an yang dikisahkan lagi oleh 'Atțār.

Nabi mengungkapkan kecintaannya kepada kaum wanita (perempuan) dengan kata-kata yang sangat jelas, begitu juga dalam tasawuf, karena pada dasarnya yang menjadi persoalan bukanlah perempuan secara kasat mata (inderawi) saja, tetapi perempuan harus dilihat secara substansi. Dalam hal ini, oleh Schimmel, keberadaan perempuan dapat ditunjukkan dengan adanya nafs. Nafs dianggap sebagai unsure feminism, yaityu unsure yang lebih rendah. ${ }^{10}$ Namun, Ibn Arabi tidak hanya berhenti isitu, ia bahkan menjelaskan mengenai unsur keperempuanan (feminism) tidak hanya menganggap nafs sebagai unsur feminism saja, melainkan telah mengembangkan pendapatnya hingga mencakup zat (esensi Ilahi). Karena aspek

${ }^{8}$ Atabik Ali, Kamus Inggris-Indonesia-Arab, Yogyakarta: Multi Karya Grafika, 2003, h. 475.

${ }^{9}$ Annemarie Schimmel, Dimensi Mistik Dalam Islam, terj. Sapardi Djoko Damono, Jakarta: Pustaka Firdaus, 2003, h. 550.

${ }^{10}$ Annemarie Schimmel, Jiwaku adalah Wanita: Aspek Feminin Dalam Spiritualitas Islam, terj. Eva Y. Nukman, Bandung: Mizan, 1998, h. 144. feminism merupakan bentuk di mana Tuhan paling dapat dikenali.

Jiwa (nafs) telah menyerahkan pada yang lebih rendah (materi, dunia, sifat-sifat negatif) adalah sifat feminine yang negatif (sifat yang menerima dan menyerah, tidak mampu melawan dan rendah). Sedangkan jiwa yang menyerahkan dirinya pada yang lebih tinggi, yaitu akal, ruh, Tuhan, adalah sifat feminism (menyerah hanya pada yang lebih tinggi). Jiwa (nafs) yang ingin berkuasa, mendominasi, meninggikan diri, mempertuhankan diri, adalah sifat maskulin negatif. Sementara jiwa (nafs) yang ingin mengalahkan nafsu amarah dan ingin naik mencapai nafsu muțma'innah yang damai bersama tuhan adalah sifat maskulin positif. Jiwa yang tenang dan damai bersama tuhan ini adalah ksatria (pria sejati) yang telah melebur dengan ruh atau akal. Manusia ini telah menjadi ruh aktif (maskulin positif) yang dapat mengontrol dan menguasai jiwa agar selaras dengan cahaya ruh dan akal (tuhan). Jika konsep Schimmel mengenai sifat keperempuanan (feminis), demikian tersebut, maka sangat mudah mengetahui seseorang apakah termasuk feminism atau maskulin, karena semua itu tergantung dari perangai (bukan bentuk fisik) manusia. Bahkan hal ini telah dijelaskan Rasul saw, bahwa beliau diutus adalah untuk menyempurnakan akhlak.

Cara lain untuk mengembalikan kepada "wanita" atau perempuan terhadap nilai-nilai hakikinya dalam membentuk "pria tuhan" yang dicita-citakan. Bagaimana pun juga (karena jiwa adalah rekan atau teman dunia-winya badan atau tubuh) wanita merupakan subjek yang sedang mencari dan merindu, yang 
selalu mencari jalan untuk menuju cinta ilahi meskipun terdapat berbagai ujian dan cobaan dalam perjalannya. Menurut Schimmel pula, bahwa kerinduan adalah sisi feminism cinta. Lebih dari itu, Rumi mencontohkan dengan langit sebagai seorang laki-laki (maskulin), dan bumi sebagai perempuan (feminim. Sehingga apa pun yang dimasukkan oleh maskulin ke dalam feminim akan menghasilkan buah dan semua benda yang tercipta menginginkan pasangannya, dan hanya penyatuan semacam itu yang dapat melahirkan anak dari tataran yang lebih tinggi.

Contoh feminim lainnya adalah cermin. Cermin dianggap merupakan peralatan perempuan yang disukai karena merupakan penyatuan dari orang yang dicintai. Jika dikemukakan dalam bahasa lain, dalam banyak halo rang yang mencintai dalam setengah kesadarannya, atau bahkan scara tidak sadar sama sekali, dianggap sebagai jiwa (pengantin) yang feminim, yang reseptif dan merindu.

Namun, cermin bukanlah satusatunya lambang jiwa perempuan yang reseptif, kaiasan-kiasan lain juga termasuk di sini, di antaranya kiasan mengenai musik (seruling) karena seruling merupakan lambang yang sangat bagus dari jiwa yang terputus hubungannya dari akar primordialnya dan terus menerus menyanyikan kerinduannya kepada tanah air. Begitu juga dengan "manusia sebagai instrument" (yang kadang-kadang terlihat jauh sehingga menyamakan syaraf atau urat nadi dengan dawai) juga merupakan bagian dari lingkup feminim.

Menurut filsafat ecofeminism manusia telah memuja tuhan sebagai maskulin (the father god) dan kurang memuja Tuhan sebagai feminim (the mother god). Akibatnya manusia mengidentifikasikan dirinya sebagai yang kuasa, aktif, terpisah dominan, padahal pemujaan Tuhan sebagai feminim (the mother God) adalah bertujuan merealisasikan eksistensi asal segala sesuatu yaitu ibu, bumi, cosmos.

Penyembahan tersebut membuat manusia mengidentifikasikan dirinya sebagai yang dekat, sebagai pemelihara, pasif, berserah diri, dan segala kualitas feminim lainnya. Kualitas tersebut akan menjadikan manusia sadar bahwa elemen-elemen dalam diri manusia, manusia sesama manusia, bumi, langit dan seluruh kosmos pada dasarnya adalah satu yang berasal dari Tuhan sebagai feminim (the mother God).

Menanggapi permasalahan tersebut, Prof. Sachiko mengatakan bahwa makna kesatuan dan makna dualitas pada dasarnya berasal dari hakekat yang satu. Dengan menggunakan Asma' al-Husna, ia telah mmebagi nama Tuhan menjadi dua, nama keagungan yang disebut sebagai jalal (kualitas maskulin) dan nama-nama Keindahan yang disebut jamal (kualitas feminim). ${ }^{11} \mathrm{Hal}$ ini berarti bahwa segala sesuatu yang berkenaan dengan Tuhan, memiliki dualitas, yaitu sisi memiliki sifat Pengasih, Penyayang, Pemaaf, namun disisi yang lain Tuhan memiliki sifat pemberi adzab, Penguasa, dan sebagainya. Hal ini juga berarti bahwa suatu saat hamba akan di-perlakukan oleh Tuhan seolaholah menjadi seorang perempuan dan disaat tertentu akan diperlakukan seperti laki-laki.

11Sachiko Murata, The Tao of Islam, h. 350. 


\section{Relevansi Semangat Sifat Keperempuanan (Feminim) dalam Tasawuf Terhadap Zaman Modern}

Annemarie Schimmel adalah sosok seseorang yang sangat memperhatikan masalah-masalah keperempuanan. Walaupun lika-liku kehidupan Annemarie Schimmel tidak berjalan mulus, tetapi dia mampu menunjukkan kemampuannya di hadapan kaum laki-laki. Pada tahun 1980 Schimmel telah menjadi Presiden International Association of the History Religion, bahkan telah menjadi perempuan pertama dan Islamologis pertama yang memegang jabatan itu.

Annemarie Schimmel memang beragama Kristen, namun dalam gerakan feminimnya (walaupun tidak secara besar-besaran mengekspos dirinya sebagai feminis muslim), maka tidaklah berlebihan apabila ia dapat disandingkan dengan feminis-feminis Islam lainnya. Hal ini terbukti dari berbagai tulisan dan beberapa penelitiannya yang selalu memperhatikan keislaman (khususnya mengenai masalah tasawuf) dan seperti yang dikatakannya sendiri, Muhammad saw adalah sosok nabi yang dikaguminya.

Sebagai peneliti dan Islamolog ulung, secara memukau Schimmel mampu menunjukkan sikap "keberhasilan" bahkan jauh melampaui kaum muslim sendiri. Kenyataan ini dapat dilihat melalui komitmen dan empatinya yang mendalam terhadap Islam, yang secara cerdas Annemarie Schimmel mampu menjelaskan Islam melalui karyanya Deciphering the Sings of God: A Phenomenological Approach to Islam.
Tentang Muhammad misalnya, dia telah membuktikan empati itu melalui magnum opus-nya, And Muhammad Is His Messenger (1985). Selain itu juga ada dua karya lainnya, Jiwaku Adalah Wanita: Aspek Feminim Dalam Spiritualitas Islam (1998) dan Akulah Angin Engkaulah Api: Hidup dan Karya Jalaluddin Rumi (1993). Karena empati yang begitu mendalam inilah, Prof. Dr. Annemarie Schimmel dapat merasakan luka mendalam yang dialami oleh umat Islam di seluruh dunia dengan terbitnya buku kontraversialnya Karya Salman Rusdhie, The Satanic Verses (Ayat-ayat setan). Dengan demikian Annemarie Schimmel diakui telah memiliki peran signifikan dalam upaya membangun konstruksi yang lebih baik bagi relasi Islam-Kristen. ${ }^{12}$ Ditambah lagi dengan sangat apresiatifnya Schimmel terhadap dua pujangga dan sufi besar pada masanya, yaitu Maulana Jalaluddin Rumi dari Turki serta "Bapak Ruhani" dari Pakistan, Muhammad Iqbal.

Penguasaan Annemarie Schimmel pada studi kebudayaan dan kesusasteraan Islam, termasuk mengenai Sufisme dan mistisisme terbukti dengan banyaknya buku dan monograf yang ditulisnya. Sehingga dengan demikian sangat layak apabila kita menyebutnya sebagai feminis Islam. Walaupun, Masignon (seorang orientalis) mencela teman-temannya dari orientalis, karena dalam mengkaji sehingga mereka tidak bisa mencapai esensi Islam itu sendiri. Dia menganggap para orientalis memiliki kelemahan tidak mampu mengekspresikan Al-Quran dalam implement-

${ }^{12}$ Hery Sucipto, Ensiklopedi Tokoh Islam Dari Abu Bakar sampai Nasr dan Qardhawi, Bandung: Mizan, 2003, h. 308. 
tasi pemikiran dalam pema-haman dan analisis. Ditambah lagi dengan tulisannya sendiri dalam buku Jiwaku Adalah Wanita: Aspek Feminim Dalam Spiritualitas Islam (1998), bahwa Annemarie Schimmel mengatakan ketidaktahuannya tentang dirinya, apakah termasuk orang yag beriman ataukah orang kafir. Yang jelas ia telah menyebutkan bahwa dirinya dan Tuhannyalah yang mengetahuinya, karena ia telah merasa dekat dengan Allah dan Muhammad saw yang dikasihinya.

Namun diakui ataupun tidak, betapa pun Schimmel cenderung memiliki sikap yang simpatik terhadap Islam, dia tidak pernah mengaku sebagai seorang muslim (muslimat). ${ }^{13} \mathrm{Hal}$ ini juga terbukti dari beberapa tulisannya yang menyatakan simpati terhadap Muhammad, al-Hallaj, Ibn Arabi (tanpa mengatakan Islam sekalipun). Dari kenyataan tersebut dapat kita tarik kesimpulan bahwa Schimmel tidak pernah mengagumi Islam sebagai ajaran atau pun pedoman hidup (normatifitas), tetapi ketertarikan Schimmel terhadap Islam hanya berdasarkan keilmuan saja.

Perlu dipahami, bahwa kualitas feminitas dan maskulinitas dalam pembahasan mengenai tema ini adalah kualitas perangai, bukan kualitas lahiriah. Pada intinya kualitas maskulinitas adalah aktif, melimpahkan, sedangkan kualitas feminitas adalah pasif, menerima dan berserah diri.

Laki-laki (maskulin) atau pun perempuan (feminim) pada dataran manusia, masing-masing memiliki sisi

${ }^{13}$ Haidar Baghir, "Fenomenologi Annemarie Schimmel", kata pengantar untuk edisi bahasa Indonesia Annemarie Schimmel, Rahasia Wajah Suci Ilahi, Bandung: Mizan, 1996, h. 9. positif dan sisi negatif yang keduanya saling melengkapi. Keseimbangan dan kesatuan ying dan yang, feminin dan maskulin, jamal dan jalal. Sebagai tujuan pencipta yang harus tercipta dalam lahiriah maupun batiniah. Karena esensi tujuan manusia (feminim atau maskulin) adalah menjadi insan kamil, yaitu manusia yang dapat menyatukan sisi lahiriah jamal dan menjadi kamal (sempurna).

Tuhan tidak pernah membedakan antara keduanya mecuali dalam iman dan ketaqwaannya. Pada prinsipnya, salah satu tujuan penciptaan manusia adalah untuk menyembah kepada Tuhan. Karena kapasitas manusia dalam hamba Tuhan, maka tidak ada perbedaan antara laki-laki dan perempuan, keduanya memiliki potensi dan peluang yang sama untuk menjadi hamba ideal (muttaqin) tanpa mengenal jenis kelamin, suku, bangsa atau kelompok etnis tertentu. Kekhususan-kekhususan yang diberikan kepada laki-laki, seperti suami setingkat lebih tinggi diatas isteri, lakilaki adalah saksi yang efektif dan diperbolehkannya poligami (bagi yang memenuhi syarat atau mampu). Tetapi hal tersebut tidak menyebabkan lakilaki menjadi hamba-hamba utama karena kelebihan-kelebihan tersebut diberikan kepada laki-laki dalam kappasitasnya sebagai anggota masya-rakat yang memiliki peran public dan social lebih ketika ayat Al-Quran diturunkan. ${ }^{14}$

Kesetaraan laki-laki dengan perempuan memiliki dua aspek. Pertama, kesetaraan dalam asal penciptaannya, yaitu dari diri yang satu (nafs wahidah).

${ }^{14}$ Nasaruddin Umar, Argumen Kesetaraan Jender Perspektif al-Quran, Jakarta: Paramadina, 2001, h. 248-252. 
Kedua, kesetaraan dalam taklif keagamaan-pembebanan dari Tuhan kepada manusia-serta pahala atau hukuman yang disebabkan oleh mereka. Seperti adanya perintah untuk bertaqwa, semua (laki-laki maupun perempuan) diperintahkan untuk ber-amal saleh dan semua (laki-laki maupun perempuan) akan masuk sorga, mereka (laki-laki maupun perempuan) yang beriman akan menjadi penolong dan mendapat rahmat. Sedangkan perbedaan yang meninggikan atau merendahkan seseorang hanyalah terletak pada nilai pengabdiannya dan ketakwaannya kepada Allah. ${ }^{15}$ Hal tersebut semakin memperjelas, bahwa kalimat-kalimat AlQuran tersebut bukan hanya ditujukan kepada salah satu jenis manusia saja, akan tetapi ditujukan kepada laki-laki maupun perempuan.

Dehumanisasi terhadap kaum perempuan, pernah terjadi dalam sejarah, bahkan sampai sekarang. Hal seperti itu sangat menyedihkan, lebihlebih dalam duania Islam. Padahal AlQuran sebagai kitab suci Islam justru sangat menghargai perempuan. Karena secara tegas Al-Quran memandang lakilaki maupun perempuan secara equal (al musawah), sehingga kekuatan perempuan sebenarnya adalah penyeimbang (balancing power) bagi kaum laki-laki. Sebagai kehidupan dianggap tidak seimbang apabila mengabaikan salah satunya. Laki-laki dan perempuan harus mampu bekerjasama secara simbiotik mutualistik jika menginginkan sebuah system kehidupan yang harmoni.

${ }^{15}$ M. Quraish Shihab, Membumikan alQuran: Fungsi dan Peran Wahyu Dalam Kehidupan Masyarakat, Bandung: Mizan, 1998, h. 269.
Perempuan adalah tiang agama. Ibarat sebuah rumah tanpa tiang, tentu akan mudah roboh, bahkan tidak mungkin bisa disebut sebagai rumah. Perempuan sholeh adalah perempuan yang memiliki budi pekerti dan pengalaman agama yang kuat. Adapun contoh wanita-wanita saleh yang dapat dicontoh diantaranya adalah Hajar (Ibu nabi Ismail, orang yang paling tabah dalam menghadapi ujian dari Allah SWT), Asiyah binti uzahim (isteri Fir'aun yang tergolong perempuan yang sangat baik pada zamannya. Selain memiliki kecantikan, ia juga memiliki kesempurnaan akhlak), Masyithah (seorang pembantu istana Fir'aun yang memiliki bayi istimewa karena bayinya dapat berbicara dengan fasih pada umur kurang dari satu tahun), Ratu Balqis atau Ratu Saba' adalah penguasa wanita zaman Nabi Sulaiman as. Yang sangat bijak, cerdas, demokrat, tidak suka kekerasan. Selain perempuan-perempuan yang telah disebutkan tadi, sebenarnya masih terdapat contoh dan kisah-kisah perempuan saleh lainnya, seperti Maryam sang gadis kecil, Khadijah wanita teladan, kemuliaan hati 'Aisyah dan ketika 'Aisyah mendapat gossip. Hal ini berarti, bahwa perempuan (tentunya tanpa mempermasalahkan unsur seksnya) memiliki potensi sama untuk berekspresi dengan melakukan segala sesuatu tanpa harus mendapat perintah ataupun larangan dari kaum laki-laki sebagaimana kaum laki-laki lainnya melakukan hal yang sama. Ataupun sebenarnya (kadang-kadang) perempuan mampu melebihi kapasitas laki-laki karena perempuan lebih unggul (dalam ibadah, ataupun permasalahan sosial lainnya) dibanding laki-laki. 
Disebutkan tadi, sangat tidak mungkin apabila perempuan selalu menjadi obyek yang terlecehkan. Bagaimana mungkin perempuan dilecehkan apabila yang dilecehkan melebihi (katakanlah jauh lebih baik atau mulia) yang mau melecehkan.

Kedudukan perempuan dalam pandangan ajaran Islam tidak sebagaimana yang diduga atau dipraktekkan oleh sebagian masyarakat. Karena pada hakekatnya, ajaran Islam telah memberikan perhatian besar serta memberi kedudukan terhormat kepada perempuan. Imam al-Ghazali misalnya, telah menulis, "Kalau kita mengembalikan pandangan pada seribu tahun, maka kita akan menemukan perempuan menikmati keistimewaan dalam bidang materi dan sosial yang tidak dikenal oleh perempuan-perempuan dikelima benua. Keadaan mereka lebih baik disbandingkan dengan keadaan perempuan-perempuan barat dewasa ini, asal saja perbedaan dalam berpakaian dan pergaulan tidak dijadikan bahan perbandingan". Hal senada juga diungkapkan oleh Mahmud Syaltut, mantan Syaikh (pemimpin tertinggi lemagalembaga Al-Azhar di Mesir), telah menulis bahwa, "Tabiat kemanu-siaan antara laki-laki dan perempuan dapat dikatakan sama. Allah telah menganugerahkan kepada laki-laki dengan menganugerahkan potensi yang cukup untuk memikul tanggung jawab untuk melakukan aktivitas (yang umum ataupun yang khusus), karena hukum syariat pun meletakkan keduanya dalam kerangka yang sama, seperti jual beli, nikah, melanggar dan dihukum serta menuntut dan menyaksikan". Sedangkan hal yang dapat mengaburkan keisti- mewaan serta memerosotkan kedudukan tersebut, di antaranya adalah kedangkalan pengetahuan keagamaan. Sehingga mustahil apabila agama (Islam) diatasnamakan untuk tujuan yang tidak dibenarkan dalam wilayah interprestasi abad modern seperti sekarang ini, perempuan dituntut untuk selalu aktif dalam memperjuangkan hak-hak mereka sendiri. Mereka dengan konsisten dan meyakinkan berpendapat berpendapat bahwa Islam sebagai agama selalu mengakomodasi kebutuh-an perempuan. Siti Khadijah ${ }^{16}$ adalah muallaf pertama dalam Islam tidak menginginkan terhadap agama yang ia anut melakukan deskriminasi terhadap perempuan. Siti Khadijah semula mempekerjakan Nabi Muhammad saw sebagai pegawai untuk menjalankan perniagaan dan kemudian meminta Nabi untuk menikahinya. Dengan demikian, sekitar empat belas abad yang lalu, Islam telah mengenal dan mengakui ketaktergantungan hukum dan ekonomi perempuan dan tetap bebas dari ayah (karena saat itu masih melekat budaya Patrialkhal, yaitu budaya di mana seluruh anggota keluarga harus tunduk dan patuh terhadap segala peraturan yang datang dari seorang ayah), saudara laki-laki, suami dan putera mereka. Namun, saat itu pula perempuan telah mampu menjadi penasehat dan kepercayaan Nabi. ${ }^{17}$ Sedangkan yang menjadi permasalahan adalah mengapa perempuan sekarang tidak pernah berpikir

16Mahmud Mahdi al-Istanbuli dan Mustafa Abu Nasr al-Syalbi, Wanita-wanita Shalihah Dalam Cahaya Kenabian, terj. Muh. Azhar LS, Yogyakarta: Mitra Pustaka, 2002, h. 18-19.

${ }^{17}$ Mai Yamani (ed.), Feminisme Dalam Islam, terj. Purwanto, Bandung: Yayasan Nuansa Cendekia, 2000, h. 298-299. 
semacam itu yang seolah-olah selalu dibantu oleh laki-laki, tetapi sebaliknya perempuan haruslah bisa (bergantian atau dengan take and give) membantu laki-laki.

Ratu kecil dari Syaba' (balqis alsughra') atau lebih tepat disebut sebagai ratu muda Syaba' yang disebut sebagai seorang Ratu Muslim sangatlah bertentangan (paradox) dengan masa jahiliah (saat itu), zaman kebodohan, sebelum kedatangan Nabi Muhammad saw diceritakan bahwa, pertemuan secara langsung antara Nabi Sulaiman as dengan Ratu Saba' merupakan salah seorang dari sedikit perempuan yang diakui telah memainkan peranan politik yang menentukan. Dia muncul dalam gambaran yang diberikan oleh seekor burung (hud-hud) kepada Raja Sulaiman as yang pada akhir ceritanya balqis kehilangan tahta dan kekayaan yang dicuri sesosok jin yang bekerja untuk Sulaiman as. Dan pada akhirnya, Balqis mendapatkan hikmah spiritual untuk tidak lagi menyembah matahari. Kisah yang sama terungkap juga pada kisahnya Zulaikha yang sampai tangannya teriris oleh tangannya sendiri akibat terpesona oleh ketampanan Yusuf as walaupun ada anggapan, bahwa kisah tersebut hanya menonjolkan juga mengenai pemanfaatan potensi. Yaitu potensi yang baik (menuju kepada perilaku shaleh untuk menuju jenjang (insane kamil) atau justeru akan memanfaatkan potensi untuk cenderung berbuat kepada kejelekan atau kekejian sebagaimana yang telah dikisahkan, yaitu mementingkan hawa nafsu dan kepentingan sesaat saja.
Feminis pertama (setidaknya yang konsen dalam masalah ini), ${ }^{18}$ yang dikenal dengan sebutan sebagai para teolog feminis, seperti Riffat Hasan, Fatima Mernissi (1940), Nawal El Sadawi, Amina Wadud Muhsin (1958).

Laki-laki dan perempuan memilki pengalaman keagamaan yang berbeda, karena proses sosialisasi yang diterimanya berbeda pula tergantung pada diri mereka masing-masing. Antara diri mereka dengan setiap konstelasi komunitas dan hubungan keduniaan serta interaksi dialektika yang melandasi kemampuan individu untuk mener-jemahkan dan menerima apakah symbol-simbol dan hukum-hukum yang dikonstruksi sedemikian rupa otentik atau tidak.

Laki-laki dan perempuan diberi kelebihan oleh Allah untuk saling melengkapi. Jika laki-laki diberi kelebihan fisik sedangkan perempuan diberi organ reproduksi, maka keduanya diarahkan untuk menjalankan fungis regenerasi. Karena secara biologis, perempuan harus menjalani fungsi reproduksi, maka kebutuhan financial dibebankan kepada laki-laki. Oleh karena itu, nafkah diarahkan sebagai upaya untuk mendukung regenerasi dan bukan sebagai legitimasi superioritas laki-laki.

Kisah-kisah wanita salehah tersebut telah menggabungkan antara gairah ibadah, kemanan, keyakinan, pengorbanan, ketaatan dan sekaligus kebaktian mereka kepada agama, sehingga bersatu menjadi suatu jiwa yang sulit dipahami. Di samping itu, mereka telah menggabungkan antara kecintaan

${ }^{18}$ Leila Ahmed, Wanita dan Gender Dalam Islam: Akar-akar Historis Perdebatan Modern, Jakarta: Lentera Basritama, 2000, h. 228. 
dan kemajuan sehingga meng-hadirkan kerinduan. Kemewahan hidup tergantikan dengan deraian air mata takut kepada Allah. ${ }^{19}$ Sebuah sikap dan perila$\mathrm{ku}$ yang sebenarnya dapat dilakukan oleh siapa pun.

Pendapat bahwa Hawa bertanggung jawab atas kesengsaraan manusia karena telah menjerumuskan Adam as adalah pendapat yang tidak islami. Hal ini berdasarkan fakta sebagai berikut; pertama, taklif Ilahi untuk tidak makan buah terlarang itu ditujukan kepada Adam as dan Hawa. Kedua, bahwa yang mendorong dan menyesatkan kedua-duanya dengan tipu daya dan sumpah palsu adalah setan, bahkan yang dimintai pertanggung-jawaban adalah Adam as bukan Hawa, oleh karena itu perintah larangan tersebut ditujukan kepada Adam as sebagai prinsip dan dipersalahkan. Ketiga, AlQuran telah menegaskan bahwa Adam as diciptakan oleh Allah untuk suatu tugas yang sudah ditentu-kan sebelum penciptaannya. Keempat, sorga saat itu belum dapat dipastikan bahwa sorga tersebut adalah sorga yang disediakan Allah untuk orangorang muttaqin kelak di akhirat. $^{20}$ Jika melihat kenyataan tersebut sangatlah jelas, bahwa apapun yang dibebankan oleh Allah kepada manusia adalah sama, tanpa melihat latar belakang dari jenis kelamin apakah laki-laki atau perempu-an. Karena sesungguhnya laki-laki dan perempuan yang muslim, mukmin, taat, benar, sabar, khusyu' bersedekah, ber-puasa

${ }^{19}$ Abdurrahman Ahmad, Wanita-wanita Sahabiyah, Peraih Ridho Ilahi, Cirebon: Pustaka Nabawi, 1422 H, h. 1-2.

${ }^{20}$ Yusuf Qardhawi, Fatwa-fatwa Kontemporer, Jil. II, Jakarta: GIP, 1993, h. 345-349. memelihara kehormatannya, dan banyak menyebut nama Allah akan samasama mendapat ampunan dan pahala besar.

Al-Quran menyebutkan bahwa Allah telah menyatakan "laki-laki atau perempuan berbuat kebaikan akan mendapat kelapangan rezekinya dan mendapatkan kehidupan yang lebih baik. Tuhan tidak akan menyia-nyiakan amal orang yang beriman, selain dijanjikan akan masuk surga,"21 mereka akan tentram dan bahagia, karena sebagian dari mereka sendiri. Dia yang menjadikan manusia sebagai penguasa bumi dan meninggikan sebagian mereka dengan beberapa derajat dengan diangkat sebagai khalifatu Allah fi al-Ardh. ${ }^{22}$

Jika laki-laki merendahkan perempuan dan tidak peduli terhadap kondisi keterbelakangan mereka, maka ini merendahkan kepada laki-laki sendiri. Akan tetapi pada sisi yang lain, jika lakilaki mencintai dan menghormati perempuan secara tulus serta berusaha menyempurnakan jati diri mereka, maka ini hanya merupakan refleksi dari kecintaan laki-laki kepada diri laki-laki sendiri, serta usaha dari kaum laki-laki untuk menyempurnakan jati diri lakilaki sendiri.

Perempuan adalah sebagian bahkan setengah dari masyarakat, ia adalah mitra laki-laki, sumber bersimpati bagi laki-laki, teman mewujudkan keharmonisan, ketenangan, ketentraman, kebahagiaan, membantu laki-laki untuk mencapai kesuksesan, membantu untuk

\footnotetext{
21QS. al-Nisa [4]: 124; al-Aḥzāb [33]: 35.

${ }^{22}$ Moh. Yasir Alimi, Jenis Kelamin Tuhan, Yogyakarta: Yayasan Kajian dan Layanan Informasi untuk Kedaulatan Rakyat (KLIK), 2003, h. 47.
} 
mengaktualisasikan kemanusiaan dan sekaligus sebagai teman perjalanan hidup. Bagi laki-laki perempuan adalah ibu yang penuh kasih saying, saudara yang simpatik, anak yang terpercaya, isteri yang taat. tetapi dalam ibadah kepada Tuhan, seolah-olah perempuan adalah "musuh" (tapi bukan sebagai musuh yang berperan sebagai antagonis sehingga layak untuk dibenci dan dijauhi), tapi hanya dijadikan sekedar sebagai pesaing untuk meraih "kecintaan" dari Tuhan.

Perbedaan yang tampak antar jenis tersebut setidaknya ada tiga macam. Pertama, perbedaan dalam persoalan individu-individu, kedua, perbedaan dalam pola pergaulan dalam masyarakat. Ketiga, perbedaan pandangan kedua jender itu untuk melangsungkan kehidupan (survival) masingmasing. Perempuan cenderung pada kehidupan yang tenang untuk membentuk iklim yang kondusif. Laki-laki ataupun perempuan memiliki perbedaan secara prinsipil, jika perempuan mengembangkan sayapnya secara perlahan untuk melindungi entitas di bawahnya (anak), sedangkan laki-laki mengembangkan sayapnya untuk terbang, sebuah ego yang sangat menonjol karena hanya mementingkan dirinya sendiri. Stabilitas hidup bagi perempuan dan revolusi bagi laki-laki untuk mengubah hidup adalah bagian kreasi dari laki-laki. Pada kenyataannya perempuan lebih jujur, berakal, cerdik dalam urusan cinta, sedangkan laki-laki lebih kuat dan berani dalam perjuangan. Namun, beberapa perbedaan tersebut hanyalah perbedaan dalam perjuangan. Namun, beberapa perbedaan tersebut hanyalah perbedaan yang muncul dari pembentukan bukan kodrati (yang suatu saat) tentunya memiliki kemungkinan untuk bisa dipertukarkan. Asalkan keduanya saling mengetahui dan memberikan kesempatan dengan cara menghargai, tidak mencela, atau jika perlu saling mengalah sekalipun.

\section{E. Penutup}

Tasawuf atau mistik Islam, menurut Annemarie Schimmel, merupa-kan kesadaran terhadap kenyataan tunggal dan cinta kepada Yang Mutlak (the Absolute), sebab kekuatan yang memisahkan antara mistik sejati dengan hanya sekedar tapa brata (asceticism) adalah cinta. Bahkan cinta sejati dapat menjadikan kenikmatan terhadap segala yang menyakitkan. Mistik dianggap sebagai hal yang misterius yang tidak dapat dicapai dengan cara-cara biasa atau dengan usaha intelektual. Sedangkan literature dan kehidupan rohaninya sulit digambarkan sebagai-mana orang buta yang menyentuh gajah, dalam penggambarannya akan mengata-kan sesuai dengan bagian tubuh yang disentuhnya itu.

Menurut Annemarie Schimmel, sifat keperempuan (feminine) dalam tasawuf dapat ditunjukkan melalui sikap manusia itu sendiri apakah mampu melepaskan nafsu amarah untuk menuju nafsu muța'innah. Karena yang melalui tema ini Schimmel berusaha mengajak kepada seluruh manusia untuk merenungkan dan mengevaluasi kembali terhadap segala motivasi pemikiran dan tindakan di dunia ini, apakah sematamata hanya memenuhi keinginan ego sehingga menyerah pada nafsu yang rendah (kualitas feminine negatif) atau untuk meningkatkan (nafsu muț- 
ma'innah). Karena yang menjadi persoalan dari feminine dalam tasawuf bukanlah tuntutan terhadap hak-hak perempuan karena telah ditindas oleh kaum laki-laki sebagaimana yang didengungkan oleh kaum feminism, akan tetapi bagaimana mengungkap sifat keperempuanan yang ada dalam tasawuf itu sendiri, seperti memiliki cinta, kasih sayang, ketaatan, kesabaran, husnu zan, dan rela berkorban.

Jika hal-hal tersebut benar-benar dilakukan, maka menimbulkan sikap merasa selalu diawasi dan memiliki sikap tanggung jawab. Karena dengan cinta akan menimbulkan khauf dan raja', kasih sayang akan menimbulkan kedamaian, sabar akan membuat selalu optimis, sedangkan rela berkorban akan menimbulkan sikap tawakal. Pada kenyataannya, sikap-sikap tersebit tidak hanya dimiliki oleh laki-laki saja, tetapi juga menjadi bagian dari perempuan. []

\section{DAFTAR PUSTAKA}

Ahmad, Abdurrahman, Wanita-wanita Sahabiyah, Peraih Ridho Ilahi, Cirebon: Pustaka Nabawi, $1422 \mathrm{H}$.

Ahmed, Leila, Wanita dan Gender Dalam Islam: Akar-akar Historis Perdebatan Modern, Jakarta: Lentera Basritama, 2000.

Ali, Atabik, Kamus Inggris-IndonesiaArab, Yogyakarta: Multi Karya Grafika, 2003.

Alimi, Moh. Yasir, Jenis Kelamin Tuhan, Yogyakarta: Yayasan Kajian dan Layanan Informasi untuk Kedaulatan Rakyat (KLIK), 2003.

Anshori, Dadang S., Membincangkan Feminisme: Refleksi Muslimah atas Peran Sosial Kaum Wanita, Bandung: Pustaka Hidayah, 1997.
Baghir, Haidar, "Fenomenologi Annemarie Schimmel", kata pengantar untuk edisi bahasa Indonesia Annemarie Schimmel, Rahasia Wajah Suci Ilahi, Bandung: Mizan, 1996.

Istanbuli, Mahmud Mahdi, dan Mustafa Abu Nasr al-Syalbi, Wanita-wanita Shalihah Dalam Cahaya Kenabian, terj. Muh. Azhar LS, Yogyakarta: Mitra Pustaka, 2002.

Murata, Sachiko, The Tao of Islam: Kitab Rujukan tentang Relasi Gender Dalam Kosmologi dan Teologi Islam, terj. Rahmani Astuti dan M.S. Nasrullah, Bandung: Mizan, 1999.

Qardhawi, Yusuf, Fatwa-fatwa Kontemporer, Jil. II, Jakarta: GIP, 1993.

Schimmel, Annemarie, Deciphering the Signs of God: A Phenomenological Approach to Islam, New York: State University of New York Press, 1994.

Schimmel, Annemarie, Dimensi Mistik Dalam Islam, terj. Sapardi Djoko Damono, Jakarta: Pustaka Firdaus, 2003.

Schimmel, Annemarie, Jiwaku adalah Wanita: Aspek Feminin dalam Spiritualitas Islam, terj. Eva Y. Nukman, Bandung: Mizan, 1998.

Shihab, M. Quraish, Membumikan alQuran: Fungsi dan Peran Wahyu Dalam Kehidupan Masyarakat, Bandung: Mizan, 1998.

Siroj, Said Aqil, Tasawuf sebagai Kritik Sosial: Mengedepankan Islam sebagai Inspirasi, Bukan Aspirasi, Bandung: Mizan, 2005.

Smith, Margaret, Rabi'ah: Pergulatan Spiritual Perempuan, terj. Dra. Jamilah Baraja, Surabaya: Risalah Gusti, 2001.

Sucipto, Hery, Ensiklopedi Tokoh Islam Dari Abu Bakar sampai Nasr dan Qardhawi, Bandung: Mizan, 2003.

Umar, Nasaruddin, Argumen Kesetaraan Jender Perspektif al-Quran, Jakarta: Paramadina, 2001. 
Yamani, Mai, (ed.), Feminisme Dalam Islam, terj. Purwanto, Bandung: Yayasan Nuansa Cendekia, 2000. 